\title{
"Exploring financial parameters and innovative orientation of banks as criteria for selecting financial partners for enterprises"
}

\begin{tabular}{|c|c|}
\hline \multirow{4}{*}{ AUTHORS } & Oleksii M. Hutsaliuk iD http://orcid.org/0000-0002-6541-4912 \\
\hline & Oksana V. Yaroshevska iD http://orcid.org/0000-0003-3569-8763 \\
\hline & Olha Yu. Kotsiurba (iD http://orcid.org/0000-0001-6356-7301 \\
\hline & Alla S. Navolokina (D https://orcid.org/0000-0003-1711-6002 \\
\hline ARTICLE INFO & $\begin{array}{l}\text { Oleksii M. Hutsaliuk, Oksana V. Yaroshevska, Olha Yu. Kotsiurba and Alla S. } \\
\text { Navolokina (2020). Exploring financial parameters and innovative orientation of } \\
\text { banks as criteria for selecting financial partners for enterprises. Banks and Bank } \\
\text { Systems, 15(1), 118-131. doi:10.21511/bbs.15(1).2020.12 }\end{array}$ \\
\hline DOI & http://dx.doi.org/10.21511/bbs.15(1).2020.12 \\
\hline RELEASED ON & Tuesday, 24 March 2020 \\
\hline RECEIVED ON & Monday, 10 February 2020 \\
\hline \multirow[t]{2}{*}{ ACCEPTED ON } & Tuesday, 03 March 2020 \\
\hline & $(\mathrm{cc}) \mathrm{EY}$ \\
\hline LICENSE & $\begin{array}{l}\text { This work is licensed under a Creative Commons Attribution } 4.0 \text { International } \\
\text { License }\end{array}$ \\
\hline JOURNAL & "Banks and Bank Systems" \\
\hline ISSN PRINT & $1816-7403$ \\
\hline ISSN ONLINE & $1991-7074$ \\
\hline PUBLISHER & LLC "Consulting Publishing Company "Business Perspectives" \\
\hline FOUNDER & LLC "Consulting Publishing Company "Business Perspectives" \\
\hline
\end{tabular}

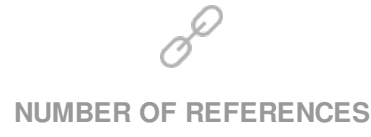

48

\section{NUMBER OF FIGURES}

0

\section{ニニ:}

NUMBER OF TABLES

9

(C) The author(s) 2022. This publication is an open access article. 


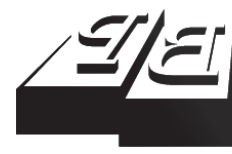

\section{BUSINESS PERSPECTIVES}

(O)

LLC "CPC "Business Perspectives"

Hryhorii Skovoroda lane, 10, Sumy, 40022, Ukraine

www.businessperspectives.org
Received on: $10^{\text {th }}$ of February, 2020 Accepted on: $3^{\text {rd }}$ of March, 2020 Published on: $24^{\text {th }}$ of March, 2020

(c) Oleksii M. Hutsaliuk, Oksana V. Yaroshevska, Olha Yu. Kotsiurba, Alla S. Navolokina, 2020

Oleksii M. Hutsaliuk, Doctor of Economics, Associate Professor, Head of the Department of Management, International European University, Ukraine.

Oksana V. Yaroshevska, Doctor of Economics, Associate Professor Professor of the Department of Economics, Classic Private University, Ukraine.

Olha Yu. Kotsiurba, Ph.D. in Economics, Associate Professor of the Department of Finance, Banking and Insurance, Central Ukrainian National Technical University, Ukraine.

Alla S. Navolokina, Ph.D. in Economics, Associate Professor of the Department of Management, International European University, Ukraine.

Oleksii M. Hutsaliuk (Ukraine), Oksana V. Yaroshevska (Ukraine), Olha Yu. Kotsiurba (Ukraine), Alla S. Navolokina (Ukraine)

\section{EXPLORING FINANCIAL} PARAMETERS AND INNOVATIVE ORIENTATION OF BANKS AS CRITERIA FOR SELECTING
FINANCIAL PARTNERS
FOR ENTERPRISES

\section{Abstract}

The article substantiates aspects that are fundamental for the economic justification of the bank selection by enterprises as the main stage in the partnership formation. It also defines the development of a bank selection procedure taking into account the financial parameters and innovative orientation of banks.

The proposed procedure for selecting banks includes two blocks. The first block is the comparison of banks in terms of reliability, which is determined based on indicators for assessing their financial risks and confidence of enterprises. The second block is the comparison of the most reliable banks according to the operational capabilities of Internet banking systems (in terms of functionality) and the intensity of promotion of innovative products and services that meet the needs of enterprises.

The proposed bank selection procedure is mainly based on applying the classification functions that allow the reliability-based differentiation as well as comparison of banks. The proposals submitted with the aim to develop classification functions, as well as the bank selection procedure as a whole, were tested based on the financial statements and general information on the Ukrainian banks' activity as of January 1, 2019. The following results were obtained while testing the developed procedure: It defines the features specific to dividing the analyzed Ukrainian banks into groups (70\% are highreliability banks, $7 \%$ are medium-reliability banks, and $23 \%$ are low-reliability banks). It also highlights the fact that reliable banks are focused on innovating and developing remote services for their business clients.

\section{Keywords}

JEL Classification

\section{INTRODUCTION}

In recent years, there has been a steady tendency in the global economic space for the rapid development of financial markets and the diversification of credit institutions. However, even in the face of fierce competition between financial intermediaries for business, banks are still the main partners in the context of providing comprehensive financial services. The existing needs for additional financing of activities (to replenish working capital, expand and modernize production, invest in innovation, etc.), maintenance of accounts, salary projects, receipt of trade and internet acquiring services and other banking products and services require prudent decisions from business organizations. In particular, in this context, it concerns the choice of banks and further harmonization of interests of both parties in the course of their credit-financial interaction. 
Banks are quite sensitive to negative changes in the environment. Therefore, along with the priorities of business partnership with banks that meet the financial expectations of enterprises, parameters of their financial condition are an important criterion for choosing banks. In addition, the innovative nature of the global economy and the development of e-commerce makes business customers expect innovative proposals from banks. These proposals include the product line extension, optimization of partner communication in the framework of remote services, simplification of access to financial services and the introduction of additional services that can be used to improve the activities of enterprises. For example, one of the innovative trends that defined banking in 2019 (Global Banking \& Finance Review, 2019) and may be of interest to business organizations is the promotion of smart banking. In particular, predictive analytics using artificial intelligence (AI-Driven Predictive Banking). Within the framework of the corresponding technology, an information platform is formed by synthesizing internal and external customer data. It is possible to build their forward-looking profiles on the basis of this platform in real time. This will allow businesses not only to improve their account management and banking operations, but also to seek financial and economic development advice in general. Thus, given the commitment of enterprises to banking innovation initiatives, it can be stated that the innovative activity of banks and their willingness to transfer innovations are among the criteria for choosing financial services partners.

\section{LITERATURE REVIEW}

\subsection{Aspects of interaction between enterprises and banks}

The issues of interaction between enterprises and banks are widely considered in the scientific literature from the perspective of different aspects the stages of the life cycle of their partnership (Zineldin, 1996) and the stability of relationships (Proença \& de Castro, 2005), information flows in the communication process (Voroneanu, 2013; Guo, 2017), the use of bank loans and their impact on improving businesses performance (Ennew \& Binks, 1996; Nielsen, Terry, \& Trayler, 1998; Lam, Lo, \& Burton, 2005; Lam \& Burton, 2006; Voroneanu, 2013), the quality of banking services and its communication with business customer loyalty and retention (Turnbull \& Gibbs, 1989; Ennew \& Binks, 1996; Pezzetti, 2004; Jobling, Walker, \& Heffernan, 2009; Fragata \& Gallego, 2010), and others. The main conclusions of these areas of research are of theoretical and practical value both for the development of enterprise strategies in the context of interaction with their main stakeholders, and for improving banking management. In particular, Zineldin (1996) emphasizes the importance of considering the cyclical nature of the development of business relationships with banks and focuses on the changes that occur at different stages of the life cycle of their partnership, namely the formation stage, the development stage, the stage of long-term relationships, the final stage or the continuation stage. Proença and de Castro (2005) identified the main factors that generate volatility in the relationship between banks and their corporate clients. These factors include: the level of negotiation effectiveness, the trading behavior of enterprises and their financial condition, the value of banking transactions, the level of financial risk arising from a relationship or a specific agreement, and the bank staff rotation policy.

Voroneanu (2013) determines that the necessary condition for establishing communication between banks and business clients and organizing their cooperation on a partnership basis is to ensure transparency of information flows. According to the author, it is important to take measures to rationalize the decision-making process to ease any tension, to promote profitable cooperation for both parties. Guo (2017), considering the aspects of communication between enterprises and banks, reveals the features of their relations from the perspective of cross-hierarchical relationships. Guo (2017) emphasizes the exchange of information through multichannel communication (through social events, personal meetings, telephone conversations, internet banking, e-mail, etc.).

Research by scientists (Ennew \& Binks, 1996; Nielsen, Terry, \& Trayler, 1998; Lam, Lo, \& Burton, 2005; Lam \& Burton, 2006; Voroneanu, 2013, etc.) 
is quite widespread and covers aspects of the positive impact of corporate credit supply on their operations and profitability. In addition, most of these studies emphasize that for companies, the ability to obtain credit is one of the important criteria for choosing a banking partner, which determines their commitment and loyalty to banks.

In the context of small business interactions with banks, Ennew and Binks (1996) examined the relationship among quality of service, customer loyalty, and retention. The authors draw the following conclusions. First, the quality of services enhances banks' ability to retain loyal business customers. Second, functional and technical quality have a positive effect on their loyalty and retention. Third, investing in quality and managing relationships with business clients can help banks increase their loyalty.

Pezzetti (2004) also draws attention to the fact that satisfaction and complexity of meeting the needs of enterprises in the process of interaction with banks affect the establishment of their long-term relationships. Similar findings are also reported in studies by Jobling, Walker, and Heffernan (2009), Turnbull and Gibbs (1989). Thus, Jobling, Walker, and Heffernan (2009) (by interviewing 23 whistleblowers working at small and medium-sized enterprises in Australia) substantiated the factors that influence the choice of banks and collectively shape the quality of service provided to small and medium-sized businesses. These factors include the ability to meet financial needs, competitive pricing, employee opportunities and online banking. According to Turnbull and Gibbs (1989), quality of service, along with the quality of staff, the nature of relationships with bank managers and the cost of services, are positioned as the most important criteria for their choice of corporate customers in South Africa.

The analysis of scientific works shows that most of them are focused on covering the issues of forming and strengthening the relations between enterprises and banks directly in the process of their partnership. This confirms the feasibility of further development of aspects of the economic rationale for choosing banks, in particular, by the criteria that reflect their financial parameters and innovation orientation. The conclusions made ne- cessitated consideration of the relevant criteria when choosing banks by clients as a whole and by their individual groups.

\subsection{Financial parameters and innovation orientation as criteria for choosing banks}

In the process of analysis of publications in this area and related research, it was found that the innovative orientation of banks and/or their financial parameters, both within the criteria of choosing banks and factors influencing the commitment and loyalty of clients, were reflected in most of them. Although in some cases superficially or veiled.

Thus, the financial parameters of banks among the criteria of their choice are considered in the research of the auditing consulting company Ernst \& Young (EY) and the European Financial Management Association (EFMA) (Efma, 2014), as well as in M. Lelissa and T. Lelissa (2017), and Poturak (2012). According to the M. Lelissa and T. Lelissa's (2017) structure of factors influencing the bank choice (obtained by processing 101 questionnaires of Ethiopian bank customers), the factor "financial performance and reputation of the bank" combines the following components: market reputation, security of funds and privacy, guarantee for depositors, levels of profitability, business activity and risk activity of banks, security of the financial environment. In Poturak (2012), along with financial stability, the most important criteria for choosing banks are the presence of a large number of ATMs, the provision of debit card services, low interest rates on loans, and trust in staff. The conclusions drawn in this paper are based on the results of a survey of bank employees of five banks in Bosnia and Herzegovina. The report of Ernst \& Young and the European Financial Management Association (Efma, 2014) also stated that financial stability is one of the main criteria for determining the credibility of banks that should be taken into account when choosing them. In addition, this study considers customer experience, tariffs and fees, and other relevant criteria.

It is also important to note that other criteria related to banks' financial status, scale of operations, and level of their financial risk are often consid- 
ered by scholars in the context of bank choice analysis, customer loyalty and commitment, including the reputation and/or image of banking institutions, their reliability and credibility.

Aregbeyen (2011) considers banks' reputation (reliability) as an important criterion for their choice (combined with other criteria) and substantiates it using the Duncan Multiple Range test.

The authority and the level of credibility of banks in the scientific literature are most often given in the context of assessing the loyalty of consumers of banking services. For example, Aldlaigan and Buttle (2005) combine parameters such as authority, connection, and congruence into a measure of commitment. This indicator reflects three forms of value: belief in the organizational competence of banks, mutually agreed and congruent values, and positive social ties. Filip and Anghel (2009) conclude that the trust in banks and their employees, the level of customer commitment, the attitude of banks to customers and their satisfaction form a positive perception of banks by potential and existing customers.

One of the most important factors influencing customer loyalty is the image of banks. Bloemer, de Ruyter, and Peeters (1998) developed a multidimensional approach to identifying the link between bank image, quality of service, customer satisfaction and customer loyalty. The authors found that market position (as a measure of image) and reliability (a measure of service quality) are the most important factors for ensuring the loyalty of private customers. Siddique (2012) emphasizes that image, together with efficient, fast and quality service in combination with on-line services, is an important factor influencing the choice of a private commercial bank by clients.

In addition to the availability of new banking products and services, scientists often consider remote service options (use of ATMs, self-service terminals, internet banking, mobile banking, etc.) within the criterion of innovation orientation, or vice versa, they offer a combination of these criteria. For example, M. Lelissa and T. Lelissa (2017) consider the criterion of "innovation and e-banking" as the leading position of the bank on the offer of new products and services, mobile and Internet banking, availability of payment terminals, ATMs and their compliance with the needs of customers, the right approach to market segmentation. In addition, the accessibility and security of e-banking services among the bank selection criteria are also presented in Denton and Chan (1991), Jobling, Walker, and Heffernan (2009), Aregbeyen (2011), Poturak (2012), Siddique (2012), Rashid (2012), Saleh, Rosman, and Nani (2013), Mwange (2017), and others.

The combination of e-banking and innovation or the incorporation of e-banking technology as a characteristic of banks' innovation orientation is linked to its innovative nature (Kashmari, Nejad, \& Nayebyazdi, 2016), including internet banking, which is the most innovative (Eriksson, Kerem, \& Nilsson, 2008; Alhinai, Albadi, Alshihi, \& AlGharbi, 2013; Rahi, 2015) and is the only service and information platform that benefits both banks and consumers (Tan \& Teo, 2000).

For banks, internet banking is, first and foremost, a tool for increasing competitiveness and market share (Johns \& Perrott, 2008; Al-Weshah, 2013; Chidindi, Niekerk, \& Matiza, 2014; Kashmari, Nejad, \& Nayebyazdi, 2016), including the expense of minimizing the cost of communication with customers, expanding the range of banking products and services. It is also the driver of customer satisfaction and loyalty (Liao \& Cheung, 2002; Casaló, Flavián, \& Guinalíu, 2007; Ahmad \& Al-Zu'bi, 2011; Chidindi, Niekerk, \& Matiza, 2014; Rahi, 2015; Sadozai, Saleem, Chuanmin, Ali, \& Marri, 2017; Gunaratnam, Kajenthiran, Umanakenan, \& Achchuthan, 2018).

In turn, for customers (both private and corporate), the main benefits of using online banking are: simplifying access to banking services and ease of use (Liao \& Cheung; 2002; Johns \& Perrott, 2008; Jobling, Walker, \& Heffernan, 2009; AlWeshah, 2013; Sadozai et al., 2017; Gunaratnam, Kajenthiran, Umanakenan, \& Achchuthan, 2017), ample opportunities to conduct financial transactions and review online finances (Eriksson, Kerem, \& Nilsson, 2008; Chidindi, Niekerk, \& Matiza, 2014; Rotchanakitumnuai \& Speece, 2004), transaction rate by operations (Liao \& Cheung, 2002; Rotchanakitumnuai \& Speece, 2004; Eriksson, Kerem, \& Nilsson, 2008; Al-Weshah, 2013). 
As part of a review of consumption of online services by business clients, Jobling, Walker, and Heffernan (2009) note that internet banking is a fundamental component of SMEs' relations with banks; attractive in that it saves time on daily banking in the workplace. Johns and Perrott (2008) consider internet banking as a technology of self-service in the context of B2B (business-to-business) relationships. They emphasize that strengthening these relationships motivates businesses to take banking technology in the long run. In addition, Monge-González (2011) concluded the following from a study of the relationship between the use of micro and small enterprises (MSE)'s internet banking and their effectiveness. First, compared to medium-sized enterprises, MSEs use less intensive internet banking services. Secondly, and as a consequence, this has a negative effect on improving their financial performance. Novokmet and Tokić (2016), on the contrary, state that the profitability of enterprises (together with industry affiliation and computer literacy of employees) influences their perception of internet banking.

Thus, based on the research, it can be confirmed that reliability (both a generic indicator of financial parameters and a factor of high reputation) and the innovative orientation of banks are interrelated and important criteria for their choice for enterprises. The following was revealed: the orientation of most researchers on the substantiation of the list of the most significant selection criteria for banks; limited proposals regarding the mechanism for comparing banks against these criteria and specifying indicators for their implementation.

\section{AIMS}

The article is aimed at generating a procedure for selecting banks as potential enterprise partners in the field of credit and financial interaction, taking into account the financial parameters of banks and their innovative orientation.

\section{METHODS}

The purpose of the article and the results obtained from the analysis of scientific sources provide grounds for proposing a procedure aimed at se- lecting alternative partner banks for enterprises in terms of the reliability (the first procedure block) and innovative orientation (the second procedure block) of the former.

Within the first block of the bank selection procedure, comparisons are made using discriminatory/ classification functions (formula (1)). According to these functions, the bank will be assigned to the group whose value of the classification function is the highest for the institution. Given that the discriminant functions in this study determine the affiliation of banks to different groups in terms of reliability, the hypothesis regarding their differentiation by high, medium and low levels of the corresponding generalization parameter is formulated.

$$
d=u_{0}+u_{1} x_{1 k m}+u_{2} x_{2 k m}+\ldots \ldots+u_{p} x_{p k m}
$$

where $d$ - the value of the discriminant function; $u_{i}$ - function coefficients that are chosen so that their averages for different groups are as different as possible; $x_{i k m}$ - the value of the discriminant variable $x$ for the $m$-th object in group $k$.

As discriminatory variables $x_{i}$ in the classification models, according to formula (1), it is proposed to use the financial parameters of banks (Table 1), which characterize their reliability from the standpoint of riskiness of activities and customer confidence. The level of financial risk of banks is considered appropriate to be measured by the indicators presented in Chmutova and Kharytonova (2017) and supplemented by the inclusion of a parameter that determines the level of risk of bank capital adequacy. In turn, trust in banks should be measured by their market share (shares of loans granted to enterprises and term deposits attracted from enterprises in the total volume of relevant indicators for the banking sector as a whole).

The basis for constructing discriminant functions is the classification division of objects into groups (using cluster analysis), and its results are adjusted using discriminant analysis in terms of the correctness of clustering. On this basis, three stages are provided substantiating the discriminatory models of bank affiliation with groups with certain levels of financial parameters to assess their reliability and verify the hypothesis formulated. 
Table 1. Financial parameters for determining bank reliability

\begin{tabular}{|c|c|c|}
\hline $\begin{array}{c}\text { Areas of bank } \\
\text { reliability } \\
\text { assessment }\end{array}$ & Indicator & $\begin{array}{l}\text { Indicator } \\
\text { designation }\end{array}$ \\
\hline \multirow{6}{*}{ Financial risks } & $\begin{array}{l}\text { Instant liquidity ratio, \% } \\
\text { (liquidity risk) }\end{array}$ & $x_{1}$ \\
\hline & $\begin{array}{l}\text { Regulatory capital adequacy } \\
\text { ratio, } \% \\
\text { (capital adequacy risk) }\end{array}$ & $x_{2}$ \\
\hline & $\begin{array}{l}\text { Net interest margin, \% } \\
\text { (interest rate risk) }\end{array}$ & $x_{3}$ \\
\hline & $\begin{array}{l}\text { The share of impairment } \\
\text { provisions in the loan } \\
\text { portfolio, \% } \\
\text { (credit risk) }\end{array}$ & $x_{4}$ \\
\hline & $\begin{array}{l}\text { The share of securities } \\
\text { impairment provisions in } \\
\text { the securities portfolio, \% } \\
\text { (investment risk) }\end{array}$ & $x_{5}$ \\
\hline & $\begin{array}{l}\text { Factor of instability of a } \\
\text { resource base, } \% \\
\text { (risk of resource base } \\
\text { instability) }\end{array}$ & $x_{6}$ \\
\hline \multirow[b]{2}{*}{ Customer trust } & $\begin{array}{l}\text { The bank's share of total } \\
\text { loans to enterprises, } \%\end{array}$ & $x_{7}$ \\
\hline & $\begin{array}{l}\text { The share of the bank in } \\
\text { the total amount of time } \\
\text { deposits attracted from } \\
\text { enterprises, } \%\end{array}$ & $x_{8}$ \\
\hline
\end{tabular}

In the first stage, given the hypothetically determined gradation of the levels (high, medium and low) of banks' reliability, their clustering is carried out using the K-means method (MacQueen, 1967), which implements the idea of forming groups according to the "closest center" principle and provides for the early setting of the number of clusters. Before clustering, a check is made for the absence of a close linear relationship between the parameters by which the grouping of objects is ensured, and objects that have atypical values are excluded from the analyzed sample. In the second stage, the discriminant analysis tool assesses the stability of clusters, the correctness of their formation and defines the classification functions for each of the groups of banks. In the third stage, first, using a taxonomic analysis (Pljuta, 1980), quantitative integrated assessment of bank reliability is carried out within individual clusters. Integral indicators are calculated on the basis of averaged values of financial parameters and taking into account their weighting coefficients $\left(a_{i}\right)$. Weighting coefficients are based on the Fishburn criterion (Fishburn, 1970), according to F-statistics (reflects the contribution of each attribute to the division of objects into groups; the greater its value, the greater the contribution to the classification of objects). Secondly, the rule of "golden section" is a qualitative interpretation of quantitative assessment, which will confirm or refute the hypothesis formulated in the study. According to this rule, all changes occur at the level of $38.2 \%$ and $61.8 \%$ (Zahorulko, 2008), and the range of [0;0.382] corresponds to the low, $(0.382 ; 0.618]$ - to the average, and $(0.618 ; 1]$ - to the high levels of the taxonomic index of the bank reliability assessment.

The second block of the bank selection procedure compares the most reliable prospective partner banks according to the "innovation orientation" criterion, in particular, analyzes:

1) completeness of the Internet banking functionality (on the list of operations offered to enterprises on-line, in particular, transactions on current accounts of business clients, servicing of salary projects and corporate cards, currency transactions, credit and deposit operations, formation of statements and billing reports, acquiring reports and budgeting, forming online applications for banking products and services, etc.);

2) the level of acceptability (promotion intensity) of product and technological innovations that meet the needs of businesses in banking.

Thus, summarizing the results of the second block of the bank selection procedure allows enterprises to identify the most innovative and reliable banking partners.

\section{RESULTS AND DISCUSSION}

According to the proposed procedures for selecting banks to form classification functions of their belonging to three groups of indicators in terms of reliability, and based on the financial statements of 77 solvent banks of Ukraine (NBU, 2019), financial indicators (as of January 1, 2019) (Table 1) are calculated. To smooth out the sample of banks by financial parameters and eliminate their high linear relationship (by paired correlation coefficients), the study excluded six banks with atypical 
values of the analyzed parameters and an indicator of the bank's share in total loans to enterprises $\left(x_{7}\right)$, respectively.

K-means clustering of Ukrainian banks and their discriminant analysis were performed using Statistica 8.0 (Cluster Analysis and Discriminant Analysis) software.

The variance analysis of clusters (in particular, the amplitude and significance levels of the F-criterion) indicates that most financial parameters are important for clustering and are used for its further implementation (Tables 2 and 3). $x_{5}$ and $x_{6}$ are excluded, for which $p$ equals 0.6157 and 0.0576 , respectively, i.e. greater than 0.05 .

Given the statistical significance of parameters selected for clustering, the primary distribution of banks into groups was obtained. As a result of the distribution, it was determined that the first cluster included 19 banks, the second -42 banks, and the third - 10 banks.

Table 2. Dispersion analysis of Ukrainian bank clusters by their reliability levels (before excluding certain financial parameters that are not significant for clustering)

\begin{tabular}{c:c:c:c:c|c|c} 
& \multicolumn{1}{c}{ Source: Own processing. } \\
\hline & $\begin{array}{c}\text { Between - } \\
\text { SS }\end{array}$ & df & $\begin{array}{c}\text { Within - } \\
\text { SS }\end{array}$ & df & F & $\begin{array}{c}\text { Signif. - } \\
\text { p }\end{array}$ \\
\hline$x_{1}$ & 30.025 & 2 & 39.975 & 68 & 25.538 & 0.0000 \\
\hline$x_{2}$ & 39.124 & 2 & 30.876 & 68 & 43.083 & 0.0000 \\
\hline$x_{3}$ & 15.266 & 2 & 54.734 & 68 & 9.483 & 0.0002 \\
\hline$x_{4}$ & 30.687 & 2 & 39.313 & 68 & 26.540 & 0.0000 \\
\hline$x_{5}$ & 0.991 & 2 & 69.009 & 68 & 0.488 & 0.6157 \\
\hline$x_{6}$ & 5.996 & 2 & 64.004 & 68 & 3.185 & 0.0576 \\
\hline$x_{8}$ & 28.575 & 2 & 41.425 & 68 & 23.453 & 0.0000 \\
\hline & & & & & & \\
\hline
\end{tabular}

Table 3. Dispersion analysis of Ukrainian bank clusters by their reliability levels (after excluding certain financial parameters that are not significant for clustering)

\begin{tabular}{c|c|c|c|c|c|c} 
& \multicolumn{1}{c}{} & \multicolumn{4}{c}{ Source: Own processing. } \\
\hline & $\begin{array}{c}\text { Between - } \\
\text { SS }\end{array}$ & $\begin{array}{c}\text { Wfithin - } \\
\text { SS }\end{array}$ & $\mathbf{d f}$ & $\mathbf{F}$ & $\begin{array}{c}\text { Signif. - } \\
\mathbf{p}\end{array}$ \\
\hline$x_{1}$ & 24.564 & 2 & 45.436 & 68 & 18.382 & 0.0000 \\
\hline$x_{2}$ & 37.456 & 2 & 32.544 & 68 & 39.131 & 0.0000 \\
\hline$x_{3}$ & 24.180 & 2 & 45.820 & 68 & 17.943 & 0.0000 \\
\hline$x_{4}$ & 32.109 & 2 & 37.891 & 68 & 28.812 & 0.0000 \\
\hline$x_{8}$ & 28.502 & 2 & 41.498 & 68 & 23.352 & 0.0000 \\
\hline
\end{tabular}

To test clusters obtained for the stability and correctness of the formation, a discriminant analysis was performed. The first classification matrix demonstrated the existence of deviations of the classification performed by the K-means method. According to Table 4, only the second group (Cluster 2), formed during the cluster analysis of bank groups, is $100 \%$ correct. The overall percentage of accuracy of the first (Cluster 1) and third (Cluster 3) groups of banks is also high, $95 \%$ and $80 \%$, respectively.

The calculation of Mahalanobis distances and posterior probabilities allowed correcting the discrepancies and completing the classification procedure. According to the adjusted classification matrix (Table 5), the first cluster included 16 banks (high/medium financial risk and low confidence), the second -50 banks (low/medium financial risk and high/medium levels of confidence), and the third - 5 banks (with high/medium levels of financial risks and trust in enterprises).

Table 4. Primary clustering results (the primary classification matrix)

Source: Own processing

\begin{tabular}{l|c|c|c|c}
\hline & $\begin{array}{c}\text { Percent } \\
\text { correct }\end{array}$ & Cluster 1 & Cluster 2 & Cluster 3 \\
\hline Cluster 1 & 94.737 & 18 & 1 & 0 \\
\hline Cluster 2 & 100 & 0 & 42 & 0 \\
\hline Cluster 3 & 80 & 0 & 2 & 8 \\
\hline Total & 95.775 & 18 & 45 & 8 \\
\hline
\end{tabular}

Table 5. The primary classification matrix transformation as a result of discriminant analysis (two adjustment stages were performed based on Squared Mahalanobis Distances and Posterior Probabilities)

Source: Own processing

\begin{tabular}{l|c|c|c|c}
\hline & $\begin{array}{c}\text { Percent } \\
\text { correct }\end{array}$ & Cluster 1 & Cluster 2 & Cluster 3 \\
\hline Cluster 1 & 100 & 16 & 0 & 0 \\
\hline Cluster 2 & 100 & 0 & 50 & 0 \\
\hline Cluster 3 & 100 & 0 & 0 & 5 \\
\hdashline Total & 100 & 16 & 50 & 5 \\
\hline
\end{tabular}

The value of Wilks' Lambda statistics, which is 0.105 (i.e., close to 0 ), and the value of the F-criterion $(\mathrm{F}(10,128)=26.73)$ at a significance 
Table 6. Discriminant analysis summary

\begin{tabular}{c|c|c|c|c|cc}
\hline $\begin{array}{c}\text { Bank reliability } \\
\text { assessment indicators }\end{array}$ & $\begin{array}{c}\text { Wilks' } \\
\text { Lambda }\end{array}$ & $\begin{array}{c}\text { Partial } \\
\text { Lambda }\end{array}$ & $\begin{array}{c}\text { F-remove } \\
\mathbf{( 2 . 6 4 )}\end{array}$ & p-value & Tolerance & $\begin{array}{c}\text { 1-Tolerance } \\
\text { (R-squared) }\end{array}$ \\
\hline $\boldsymbol{x}_{\mathbf{1}}$ & 0.157 & 0.666 & 16.035 & 0.000 & 0.887 & 0.113 \\
\hline $\boldsymbol{x}_{\mathbf{2}}$ & 0.173 & 0.606 & 20.783 & 0.000 & 0.780 & 0.220 \\
$\boldsymbol{x}_{3}$ & 0.155 & 0.676 & 15.349 & 0.000 & 0.889 & 0.111 \\
\hline $\boldsymbol{x}_{\mathbf{4}}$ & 0.230 & 0.456 & 38.190 & 0.000 & 0.822 & 0.178 \\
$\boldsymbol{x}_{\mathbf{8}}$ & 0.120 & 0.877 & 4.498 & 0.015 & 0.930 & 0.070 \\
\hline
\end{tabular}

Note: Number of variables in the model: 5; Grouping: 3 groups; Wilks' Lambda: 0.10485 approx. $F(10,128)=26.730 ; p<$ 0.0000 .

Table 7. The results of the integrated assessment of the Ukrainian banks reliability within the existing clusters

Source: Own processing.

\begin{tabular}{|c|c|c|c|c|c|c|c|}
\hline \multirow{3}{*}{ Cluster } & \multicolumn{5}{|c|}{ Average values and weights $\left(a_{i}\right)$ of banks' financial parameters } & \multirow{3}{*}{\multicolumn{2}{|c|}{$\begin{array}{c}\text { Value and rating of taxonomic } \\
\text { indicators for assessing the } \\
\text { reliability of banks by their } \\
\text { groups, } I_{i}\end{array}$}} \\
\hline & \multirow{2}{*}{$\begin{array}{c}x_{1} \\
a=0.133\end{array}$} & \multirow{2}{*}{$\begin{array}{c}x_{2} \\
a=0.333\end{array}$} & \multirow{2}{*}{$\begin{array}{c}x_{3} \\
a=0.067\end{array}$} & \multirow{2}{*}{$\begin{array}{c}x_{4} \\
a=0.267\end{array}$} & \multirow{2}{*}{$\begin{array}{c}x_{8} \\
a=0.200\end{array}$} & & \\
\hline & & & & & & & \\
\hline Cluster 1 & 185.402 & 62.794 & 10.539 & 21.698 & 0.145 & 0.243 & 3 \\
\hline Cluster 2 & 87.425 & 26.727 & 5.317 & 11.847 & 1.328 & 0.770 & 1 \\
\hline Cluster 3 & 69.859 & 15.676 & 2.333 & 66.240 & 6.204 & 0.598 & 2 \\
\hline
\end{tabular}

level of $p<0.0000$ (Table 6), indicate the quality of the discriminant analysis. Therefore, its results can be used to interpret the results of assessing the bank reliability and to test the formulated hypothesis for the gradation of its levels.

The calculated taxonomic indicators for assessing the reliability of Ukrainian banks in terms of their groups (Table 7) suggest that the banks of the second cluster have the highest level of reliability and the first cluster - the lowest. In turn, given the "golden section" scale for the correlation of quantitative and qualitative levels of the integral indicator, the hypothesis about the distinction of banks with high, medium and low levels of reliability was confirmed. In particular, the values of the taxonomic indicator of bank reliability assessment are as follows: for the first cluster $\left(I_{1}=0.242\right)$ it falls within the interval [0; 0.382] (low level); for the third cluster $\left(\mathrm{I}_{3}=0.598\right)$ it is $(0.382 ; 0.618]$ (corresponds to the average level); and for the second cluster $\left(\mathrm{I}_{2}=0.770\right)$ it is $(0.618 ; 1]$ (corresponds to the high level).

As a result of the discriminant analysis and analytical confirmation of the hypothesis, classification functions for banks with low (formula (2)), medium (formula (3)) and high levels of their reliability (formula (4)) were constructed:

$$
\begin{aligned}
& d=-32.976+0.087 x_{1}+0.381 x_{2}+ \\
& +1.624 x_{3}+0.301 x_{4}+1.251 x_{8}, \\
& d=-31.122+0.040 x_{1}+0.282 x_{2}+ \\
& +0.706 x_{3}+0.462 x_{4}+2.835 x_{8}, \\
& d=-8.189+0.044 x_{1}+0.180 x_{2}+ \\
& +0.815 x_{3}+0.158 x_{4}+1.866 x_{8} .
\end{aligned}
$$

Substituting the values of the financial parameters $\left(x_{1}, x_{2}, x_{3}, x_{4}, x_{8}\right)$ of those banks that are considered as potential partners by the enterprise in three classification functions, as indicated in the methodology, it is possible to determine and compare their reliability levels.

The data in Table 5 and Table 7 and the constructed discriminant functions indicate that 50 banks from Cluster 2 are the most reliable potential partners for enterprises. In addition, comparing the banks according to the "innovative orientation" criterion, it would be advisable to consider three banks of Cluster 3 (characterized by medium reliability level), which are state-owned and have government support and preferences. 
Table 8. Results of comparison of Ukrainian banks on the functionality of Internet banking systems for servicing enterprises

\begin{tabular}{|c|c|c|c|c|c|c|c|c|c|c|}
\hline \multirow[t]{2}{*}{ Bank } & \multirow[t]{2}{*}{$\begin{array}{c}\text { The name of the Internet banking } \\
\text { system }\end{array}$} & \multicolumn{8}{|c|}{$\begin{array}{l}\text { Criteria for comparing the } \\
\text { functionality of Internet banking } \\
\text { systems (CR_1-CR_8) }\end{array}$} & \multirow[t]{2}{*}{$\begin{array}{l}\text { Ability to test } \\
\text { demo on the bank's } \\
\text { website }\end{array}$} \\
\hline & & 1 & 2 & 3 & 4 & 5 & 6 & 7 & 8 & \\
\hline PRIVATBANK & Privat24 for business & + & + & + & + & + & + & - & + & + \\
\hline OSCHADBANK & CORP2 Internet-Client-Bank & + & + & + & + & + & - & - & - & - \\
\hline Ukreximbank & Web-iFOBS & + & + & + & - & + & - & - & - & - \\
\hline UKRGASBANK & Client-Internet Bank iTiny & + & + & + & - & + & - & - & - & - \\
\hline Raiffeisen Bank Aval & $\begin{array}{l}\text { Raiffeisen Business Online (web } \\
\text { banking for iBank2UA business clients) }\end{array}$ & + & + & + & - & + & + & + & - & - \\
\hline ALFA-BANK & Web-iFOBS & + & + & + & - & + & - & - & - & - \\
\hline UKRSIBBANK & StarAccess & + & + & + & + & + & + & - & + & - \\
\hline OTP BANK & $\begin{array}{l}\text { OTP online } \\
\text { (Web-iFOBS) }\end{array}$ & + & + & + & - & + & - & - & - & - \\
\hline CREDIT AGRICOLE BANK & OPTIM CLIC Internet Banking Service & + & + & + & - & + & - & - & + & - \\
\hline PROCREDIT BANK & $\begin{array}{l}\text { Web banking for iBank2UA business } \\
\text { clients }\end{array}$ & + & + & + & - & + & - & + & - & - \\
\hline KREDOBANK & Web-iFOBS & + & + & + & - & + & - & + & - & - \\
\hline ING Bank Ukraine & InsideBusiness Payments & + & + & - & + & + & - & - & + & - \\
\hline FUIB & Pumb Online Corporate & + & + & + & + & + & - & - & + & + \\
\hline Joint-Stock Bank Pivdennyi & Web-iFOBS & + & + & + & - & + & - & - & + & + \\
\hline TASCOMBANK & $\begin{array}{l}\text { Web banking for iBank2UA business } \\
\text { clients }\end{array}$ & + & + & + & - & + & + & + & + & - \\
\hline BANK CREDIT DNIPRO & Freebank & + & + & + & + & + & - & - & - & - \\
\hline MEGABANK & Internet-Client-bank iTiny & + & + & - & - & + & - & - & - & - \\
\hline UNIVERSAL BANK & $\begin{array}{l}\text { Web banking for iBank2UA business } \\
\text { clients }\end{array}$ & + & + & + & - & + & + & + & - & - \\
\hline IIB & Web-iFOBS & + & + & + & - & + & - & - & - & - \\
\hline $\begin{array}{l}\text { INVESTMENT AND SAVINGS } \\
\text { BANK }\end{array}$ & $\begin{array}{l}\text { Internet-Client-bank } \\
\text { (the Internet banking system name is } \\
\text { not specified on the bank's website) }\end{array}$ & + & + & - & + & + & - & - & - & - \\
\hline
\end{tabular}

Note: CR_1 - current account transactions and statements; CR_2 - foreign exchange transactions (purchase, sale and conversion of foreign currency, SWIFT), CR_3 - salary project; CR_4- corporate card management; CR_5 - loans and deposits; CR_6 - viewing acquiring reports; CR_7 - view budgeting reports; CR_8 - additional services that extend the functionality of the Internet banking system.

20 banks out of 53 were selected (with a share exceeding $1 \%$ of total deposits by enterprises in the banking sector $\left(x_{8}\right)$ ) to approve the proposals for the implementation of the second block of the bank selection procedure. The results of comparing these banks with the breadth of functionality of Internet banking systems and the intensity of promotion of product and technological innovations in corporate banking are presented in Tables 8 and 9, respectively.

The analysis of banks' internet banking systems, according to the instructions for users and demo versions presented on their official sites, revealed both common and different characteristics. In particular, most of them are a separate module of various Client-Bank remote service systems, which are intended to provide e-banking services to clients for legal entities with the support of two access channels - Internet Banking and PC-Banking. All Internet banking systems are also integrated with accounting programs, providing communication with the bank (e-mail correspondence or online chatting) and SMS-informing clients.

At the same time, according to Table 8, the functionality of Internet banking systems is not identical, but in terms of its completeness by special criteria, reflecting the possibilities of online banking of enterprises, PRIVATBANK, Raiffeisen Bank Aval, UKRSIBBANK, FUIB, TASKOMBANK and UNIVERSAL BANK have advantages over other banks. 
Table 9. Comparison results of Ukrainian banks on the intensity of innovation promotion in the field of enterprise servicing

\begin{tabular}{|c|c|c|c|c|c|c|c|c|c|c|}
\hline \multirow[t]{2}{*}{ Bank } & \multicolumn{10}{|c|}{$\begin{array}{l}\text { Product and technological innovations of banks } \\
\qquad(\text { CR_9-CR_18) }\end{array}$} \\
\hline & 9 & 10 & 11 & 12 & 13 & 14 & 15 & 16 & 17 & 18 \\
\hline PRIVATBANK & + & - & + & + & + & - & + & + & + & + \\
\hline OSCHADBANK & + & - & + & - & + & - & + & + & - & - \\
\hline Ukreximbank & + & - & + & - & + & - & + & + & - & - \\
\hline UKRGASBANK & + & - & + & - & + & + & + & + & - & - \\
\hline Raiffeisen Bank Aval & + & - & + & - & + & + & + & + & + & - \\
\hline ALFA-BANK & + & - & + & - & + & + & + & + & + & + \\
\hline UKRSIBBANK & + & - & + & - & + & - & + & + & - & + \\
\hline OTP BANK & + & - & + & - & + & + & + & + & + & - \\
\hline CREDIT AGRICOLE BANK & + & - & + & - & + & + & + & + & + & - \\
\hline PROCREDIT BANK & + & - & + & - & + & + & + & + & + & - \\
\hline KREDOBANK & + & + & + & - & + & - & + & + & - & + \\
\hline ING Bank Ukraine & - & - & - & - & + & - & + & - & - & + \\
\hline FUIB" & + & - & + & - & - & - & + & + & + & + \\
\hline Joint-Stock Bank Pivdennyi & + & - & + & - & + & - & + & + & + & - \\
\hline TASCOMBANK & - & - & + & - & + & - & + & + & - & + \\
\hline BANK CREDIT DNIPRO & + & - & + & - & - & - & + & + & - & - \\
\hline MEGABANK & + & + & + & - & + & - & + & + & - & - \\
\hline UNIVERSAL BANK & + & - & + & - & - & - & + & + & + & - \\
\hline IIB & - & - & + & - & + & - & + & + & - & - \\
\hline INVESTMENT AND SAVINGS BANK & + & - & + & - & - & - & + & + & - & - \\
\hline
\end{tabular}

Comparison of banks in terms of product and technological innovation acceptability is made taking into account key banking innovations in the banking system of Ukraine to service large enterprises, small and medium-sized businesses: opening an online deposit (application for ordering a deposit product is submitted through the website or via the Internet banking system) (CR_9); express lending under the simplified procedure (CR_10); deposit security (CR_11); P2B lending (CR_12); crediting of commercial real estate (CR_13); financing the development and introduction of innovations at the enterprises (CR_14); revolving credit lines and overdraft facilities (CR_15); NFC (Near Field Communication) technologies (including contactless - corporate and/ or employee payroll cards) (CR_16); simplified procedures for crediting trade revenue (through self-service terminals, through online collection, etc.) (CR_17); mobile applications (for tablets and smartphones) that are the mobile version of Internet banking systems (CR_18).

Summarizing the results of the comparative analysis of Ukrainian banks by individual criteria to determine their level of innovation orientation (based on Tables 8 and 9) allows us to conclude that the following banks occupy the highest positions in the rating of innovation-oriented reliable banks: PRIVATBANK, Raiffeisen Bank Aval, UKRSIBBANK, ALFA-BANK, FUIB, CREDIT AGRICOLE BANK, CREDOBANK, PROCREDIT BANK, and TASCOMBANK.

In general, based on the completeness of the Internet banking system functionality, the level of intensity of innovation promotion, as well as the scale of its own innovative developments, PRIVATBANK the undisputed leader against the background of other banking institutions analyzed. Thus, among the additional functions of the Internet banking system Privat24 for business, the bank offers: accounting online and working hours; creation of on-line applications for terminal installation, revenue collection and documentary operations; insurance, ticketing and rental services; possibility of re-registering a business, etc. The innovations offered by the bank for business clients should include: electronic document services (for exchanging electronic documents with partners) and electronic reporting (for reporting to regulatory bodies), assessing customer loyalty and rapid verification of counterparties, QR code payment (including using PrivatPayBot, which is a Telegram chatbot that allows creation $\mathrm{QR}$ codes to pay for goods to customers and receive payment information), organizing video-conferences, etc. 


\section{CONCLUSION}

The procedure for selecting banks proposed by the authors from the point of view of enterprises is based on a comparison of potential banking partners according to the criteria of "reliability" and "innovation orientation".

As for the first block, a procedure has been developed using classification functions that take into account the financial parameters of banks (characterizing financial risks and confidence of enterprises) and determine their reliability levels (high, medium or low). The validity of the formation and economic interpretation of classification functions that differentiate banks depending on their reliability levels is determined by the results of using cluster, discriminatory (to cluster banks and assess its correctness) and taxonomic analyses (to integrate the reliability of individual groups of banks).

The second block of the procedure includes the comparison of the most reliable banks in terms of the completeness of the Internet banking systems functionality and the intensity of technological and product innovations, that are widespread in the national banking system and meet the needs of enterprises in terms of banking services.

As the proposed procedure was implemented, the hypothesis formed in the study process regarding the feasibility of differentiating the bank reliability levels was confirmed. Financial indicators as of January 1, 2019 allow concluding that more than two thirds of Ukrainian banks (namely 70\%) have a high reliability level (the taxonomic indicator of the reliability assessment for this group of banks is 0.770 ) and can be considered as potential partners for enterprises. At the same time, most Ukrainian state-owned banks have been found to perform high-risk activities, but their credibility in the business sector is still quite high due to state guarantees. The study of innovative banking proposals and the list of services offered to enterprises online showed that the analyzed Ukrainian banks (which are considered reliable) are mainly focused on transferring and producing innovations, as well as on developing the remote servicing systems for their business clients.

The advantages of the developed procedure are: implementation logic according to the hierarchical principle (assumes agreed conclusions by stages); objectivity of the results of the bank reliability assessment (based on their financial statements) and ease of interpretation; an integrated approach to the innovation orientation of banking institutions. Using the suggestions presented in the article will allow business executives to make economically sound decisions about choosing reliable banking partners that are focused on innovation. This, in turn, provides high-quality, affordable and secure remote servicing for enterprises, and through the use of innovative banking products and services helps to improve the organization of individual internal business processes in enterprises, solving their financial and non-financial problems.

\section{AUTHOR CONTRIBUTIONS}

Conceptualization: Oleksii M. Hutsaliuk, Oksana V. Yaroshevska, Olha Yu. Kotsiurba.

Data curation: Oksana V. Yaroshevska, Alla S. Navolokina.

Formal analysis: Oleksii M. Hutsaliuk, Oksana V. Yaroshevska, Olha Yu. Kotsiurba, Alla S. Navolokina. Investigation: Oleksii M. Hutsaliuk, Oksana V. Yaroshevska, Alla S. Navolokina.

Methodology: Oleksii M. Hutsaliuk, Olha Yu. Kotsiurba, Alla S. Navolokina.

Supervision: Oleksii M. Hutsaliuk.

Writing - original draft: Oleksii M. Hutsaliuk, Oksana V. Yaroshevska, Olha Yu. Kotsiurba, Alla S.

Navolokina.

Writing - reviewing \& editing: Oleksii M. Hutsaliuk, Oksana V. Yaroshevska, Olha Yu. Kotsiurba, Alla S. Navolokina. 


\section{REFERENCES}

1. Ahmad, A. M. K., \& Al-Zu'bi, H. A. (2011). E-banking functionality and outcomes of customer satisfaction: an empirical investigation. International Journal of Marketing Studies, 3(1), 50-65. https://doi.org/10.5539/ ijms.v3n1p50

2. Aldlaigan, A., \& Buttle, F. (2005). Beyond satisfaction: customer attachment to retail banks. International Journal of Bank Marketing, 23(4), 349-358. https://doi. org/10.1108/02652320510603960

3. Alhinai, Y. S., Albadi, A., Alshihi, H., \& Al-Gharbi, K. (2013). Investigating determinants of E-banking adoption by individuals: comparing the impact of system characteristics and user traits. International Review of Management and Business Research, 2(2), 371-387. Retrieved from https://pdfs.semanticscholar. org/90cf/01e884a9dc7cbe4e358ca 21228b108f110e3.pdf

4. Al-Weshah, G. A. (2013). The role of internet banking in continuous improvement areas: quantitative evidence from Jordanian bank. International Journal of Business Performance Management, 14(2), 181-196. https://doi.org/10.1504/ IJBPM.2013.052950

5. Aregbeyen, O. (2011). The Determinants of bank selection choices by customers: recent and extensive evidence from Nigeria. International Journal of Business and Social Science, 2(22), 276-288. Retrieved from http://ijbssnet. com/journals/Vol_2_No_22_December_2011/32.pdf

6. Bloemer, J., de Ruyter, K., \& Peeters, P. (1998). Investigating drivers of bank loyalty: the complex relationship between image, service quality and satisfaction. International Journal of Bank Marketing, 16(7), 276-286. https://doi. org/10.1108/02652329810245984

7. Casaló, L. V., Flavián, C., \& Guinalíu, M. (2007).The role of security, privacy, usability and reputation in the development of online banking.

Online Information Review,

31(5), 583-603. https://doi. org/10.1108/14684520710832315

8. Chidindi, S., Niekerk, J., \& Matiza, T. (2014). Perceptions of electronic banking services by clients in the Limpopo province of South Africa. Mediterranean Journal of Social Sciences, 5(8), 253-267. https://doi. org/10.5901/mjss.2014.v5n10p253

9. Chmutova, I. M., \& Kharytonova, V. S. (2017). Ryzyk-oriientovanyi pidkhid do formuvannia finansovoi stratehii banku [The risk-oriented approach to the bank financial strategy development]. Ekonomika rozvytku - Economics of Development, 4(84), 59-67. (In Ukrainian).

10. Denton, L., \& Chan, A. K. K. (1991). Bank selection criteria of multiple bank users in Hong Kong. International Journal of Bank Marketing, 9(5), 23-34. https://doi. org/10.1108/02652329110007129

11. Ennew, C. T., \& Binks, M. R. (1996). The impact of service quality and service characteristics on customer retention: small business and their banks in the U.K. British Journal of Management, 7(3), 219-230. https://doi. org/10.1111/j.1467-8551.1996. tb00116.x

12. Eriksson, K., Kerem, K., \& Nilsson, D. (2008). The adoption of commercial innovations in the former central and Eastern European markets: The case of Internet banking in Estonia. The International Journal of Bank Marketing, 26(3), 154-169. https://doi. org/10.1108/02652320810864634

13. Filip, A., \& Anghel, L. D. (2009). Customer loyalty and its determinants in a banking services environment. Amfiteatru Economic, 11(26), 288-297. Retrieved from https://www. researchgate.net/publication/227349253_Customer_Loyalty_and_its_Determinants_in_a_ Banking_Services_Environment
14. Fishburn, P. (1970). Utility theory for decision making (224 p.). New York: John Wiley \& Sons, Inc.

15. Fragata, A., \& Gallego, P. (2010). The importance of perceived service quality in banking loyalty for large business customers (Monográfico) (pp. 151-164). Revista de la Facultad de Ciencias Económicas y Empresariales, Universidad de León. http://dx.doi.org/10.18002/ pec.v0i2010.768

16. Gunaratnam, A., Kajenthiran, K., Umanakenan, R., \& Achchuthan, S. (2018). Factors influencing on e-Banking practices: Evidence from Sri Lanka. Journal of Sociological Research, 9(1), 1-14. https://doi.org/10.5296/jsr. v9i1.11989

17. Guo, Y. (2017). Implementing relationship banking strategies and techniques and improving customer value. Finance and Market, 2(2). http://dx.doi. org/10.18686/fm.v2i2.980

18. Hedayatnia, A., \& Eshghi, K. (2011). Bank selection criteria in the Iranian retail banking industry. International Journal of Business and Management, 6(12), 222-231. http://dx.doi.org/10.5539/ijbm. v6n12p222

19. Jobling, E., Walker, G., \& Heffernan, T. (2009). Service quality attributes SME's desire in their choice and retention of a bank: an Australian perspective. International Review of Business Research Papers, 5(3), 12-25. Retrieved from https://www.researchgate.net/ publication/228505718_Service_Quality_Attributes_SME's_ Desire_In_Their_Choice_And_ Retention_Of_A_Bank_An_Australian_Perspective

20. Johns, R., \& Perrott, B. (2008). The impact of Internet banking on business-customer relationships (are you being self-served?). The International Journal of Bank Marketing, 26(7), 465-482. https://doi. org/10.1108/02652320810913846

21. Kashmari, A., Nejad, A. H. G., \& Nayebyazdi, A. (2016). Impact of 
electronic banking innovations on bank deposit market share. Journal of Internet Banking and Commerce, 21(1), 1-12. Retrieved from https://www.researchgate. net/publication/301678368_Impact_of_Electronic_Banking_Innovations_on_Bank_Deposit_ Market_Share

22. Lam, R., \& Burton, S. (2006). SME banking loyalty: A qualitative study in Hong Kong. International Journal of Bank Marketing, 24(1), 37-52. https://doi. org/10.1108/02652320610642335

23. Lam, R., Lo, H. P., \& Burton, S. (2005). Investigating the drivers of SME's banking loyalty in Hong Kong. Proceedings of the Australian and New Zealand Marketing Academy (ANZMAC) Conference (pp. 172-180). Perth, Australia. Retrieved from https:// researchers.mq.edu.au/en/publications/investigating-the-drivers-ofsmes-banking-loyalty-in-hongkong

24. Lelissa, M. B., \& Lelissa, T. B. (2017). Determinants of bank selection choices and customer loyalty the case of Ethiopian banking sector. European Journal of Business and Management, 9(13), 9-24. http://dx.doi. org/10.2139/ssrn.2967327

25. Liao, Z., \& Cheung, M. (2002). Internet-based e-banking and consumer attitudes: an empirical study. Information \& Management, 39(4), 283-295. https://doi.org/10.1016/S03787206(01)00097-0

26. Efma. (2014). Looking at the bank from the customer's point of view (Report). Ernst \& Young, European Financial Management Association. Retrieved from https://www.efma.com/assets/ content/study/2014/looking_at_ the_bank_from_the_customer_s_ point_of_view/1-189JPM_summary.pdf

27. MacQueen, J. (1967). Some methods for classification and analysis of multivariate observations. In Proceedings of the Fifth Berkeley Symposium on Mathematical Statistics and Probability (pp. 281-297).
Retrieved from https://pdfs.semanticscholar.org/a718/b85520bea702533ca9a5954c33576fd162b0. pdf?_ga $=2.729865$ -

79.1525649568.1583477945-51902735.1583477945

28. Monge-González, R. (2011). The impact of Internet banking on the performance of micro and small enterprises in Costa Rica: A randomized controlled experiment (IDB Working Paper Series No. IDB-WP-242). InterAmerican Development Bank (IDB), Washington. Retrieved from https://www.econstor.eu/ bitstream/10419/88971/1/IDBWP-242.pdf

29. Mwange, A. (2017). Determinants of bank selection criteria: the case of University of Zambia Students. Imperial Journal of Interdisciplinary Research, 3(3), 345-355. Retrieved from https:// pdfs.semanticscholar.org/f8f9/4ce fbbe935744560e20d264989beda6 8362b.pdf

30. National Bank of Ukraine (NBU). (2019). Banking system indicators. Retrieved from https://old.bank. gov.ua/control/en/publish/ article?art_id=34705283\&cat_ id $=34798612$

31. Nielsen, J. F., Terry, C., \& Trayler, R. M. (1998). Business banking in Australia: A comparison of expectations. International Journal of Bank Marketing, 16(6), 253-263. https://doi. org/10.1108/02652329810241393

32. Novokmet, A. K., \& Tokić, I. (2016). Adoption of Internet banking service within the corporate sector: evidence from newly acceded EU country. In Proceedings of the International Scientific Conference "Finance and Accounting in Creating Information about Financial Position of Reporting Entities." Katowice, Poland. Retrieved from https://bib. irb.hr/datoteka/860544.Kundid_ Novokmet_-_Tokic.pdf

33. Pezzetti, R. (2004). Bank-firm customer relations in the new competitive environment: prospects for relationship banking. Quaderno di Ricerca Research Booklet No. 7. Faculty of Economics, University of Pavia. Retrieved from https:// www.academia.edu/1998622/ Bank-firm_customer_relations_ in_the_new_competitive_environment_prospects_for_relationship_banking

34. Pljuta, V. (1980). Sravnitelnyy mnogomernyy analiz $\mathrm{v}$ ekonomicheskikh issledovaniyakh. Metody taksonomii i faktornogo analiza [Multidimensional comparative analysis in Economic Research. Taxonomy and factor analysis methods]. Moscow: Statistika. (In Russian). Retrieved from https://www.twirpx.com/ file/108986/

35. Poturak, M. (2012). Marketing factors influencing bank selection in Bosnia and Herzegovina. CEA Journal of Economics, 7(2), 5-16. Retrieved from https://journal. cea.org.mk/index.php/ceajournal/ article/view/11

36. Proença, J. F., \& de Castro, L. M. (2005). "Stress" in business relationships: a study on corporate bank services. International Journal of Bank Marketing, 23(7), 527-541. https://doi. org/10.1108/02652320510629890

37. Rahi, S. (2015). Moderating role of brand image with relation to Internet banking and customer loyalty: a case of branchless banking. Journal of Internet Banking and Commerce, 20(3). http://dx.doi.org/10.4172/12045357.1000131

38. Rashid, M. (2012). Bank selection criteria in developing country: evidence from Bangladesh. Asian Journal of Scientific Research, 5(2), 58-69. https://doi. org/10.1108/02652329810245984

39. Rotchanakitumnuai, S., \& Speece, M. (2004). Corporate customer perspectives on business value of Thai Internet banking. Journal of Electronic Commerce Research, 5(4), 270-286. Retrieved from http://web.csulb.edu/journals/jecr/ issues/20044/Paper5.pdf

40. Sadozai, A. M., Saleem, A., Chuanmin, S., Ali, M. R., \& Marri, M. Y. K. (2017). Factors 
affecting customers' satisfaction in online banking: empirical evidence from developing countries. International Journal of Advanced Biotechnology and Research, 8(2), 96-104. Retrieved from https://www.researchgate. net/publication/316786038_Factors_Affecting_Customers'SSatisfaction_in_Online_Banking_Empirical_Evidence_from_Developing_Countries

41. Saleh, M. S., Rosman, M. R., \& Nani, N. K. (2013). Bank selection criteria in a customers perspective. Journal of Business and Management, 7(6), 15-20. Retrieved from https://pdfs. semanticscholar.org/af52/36ele 31 fe62302143dcad96a8d65583b af21.pdf

42. Siddique, Md. N.-E-A. (2012). Bank selection influencing factors: a study on customer preferences with reference to Rajshahi city. Asian Business Review, 1(1), 8187. https://doi.org/10.18034/abr. vli1.147

43. Tan, M., \& Teo, T. S. H. (2000). Factors influencing the adoption of Internet banking. Journal of the Association for Information Systems, 1(1). Retrieved from https://doi. org/10.17705/1jais.00005

44. Global Banking \& Finance Review. (2019, February 1). 3 Major Areas of Banking Poised for AI-Driven Disruption in 2019. Retrieved from https://www.globalbankingandfinance.com/3-major-areas-ofbanking-poised-for-ai-drivendisruption-in-2019/

45. Turnbull, P. W., \& Gibbs, M. J. (1989). The selection of banks and banking services among corporate customers in South
Africa. International Journal of Bank Marketing, 7(5), 36-39. https://doi. org/10.1108/02652328910134662

46. Voroneanu, C. B. (2013). The credit relationship between banks and companies and its effects on the real economy. Management Strategies Journal, 21(3), 105-112. Retrieved from https://ideas.repec.org/a/brc/ journl/v21y2013i3p105-112.html

47. Zahorulko, A. V. (2008). Chyselni metody u mekhanitsi [Numerical methods in mechanics] (186 p.). Sumy: SumDU. (In Ukrainian). Retrieved from http://essuir.sumdu. edu.ua/handle/123456789/1777

48. Zineldin, M. (1996). Bankcorporate client "partnership" relationship: benefits and life cycle. International Journal of Bank Marketing, 14(3), 14-22. https://doi. org/10.1108/02652329610113135 